\title{
Policy Implementation of BNN Province Lampung in Program Prevention to Eradicate Abuse and Illegal Circulation of Narcotic (P4GN) during the Covid-19 Pandemic
}

\author{
Sri Riski \\ Faculty of Law \\ Lampung University \\ Lampung, Indonesia \\ sri.riski@fh.unila.ac.id
}

\author{
Damanhuri Warganegara \\ Faculty of Law \\ Lampung University \\ Lampung, Indonesia
}

\begin{abstract}
Strategy in preventing the circulation of narcotics is one form of performance carried out by the National Narcotics Agency and cooperates with various agencies both from government agencies, nongovernment, and also among the public in intercepting the circulation of narcotics in province Lampung. This study aims to find out how to implement the policy of the National Narcotics Agency (ABBREVIATED BNN) Province Lampung in the prevention of the eradication of abuse and illicit circulation of narcotics (P4GN) in Lampung province. Where in the study in 2021 researchers and $B N N$ can be more optimal and innovate in the prevention program of eradication of narcotic abuse (P4GN) during the pandemic covid-19. The big target that will be achieved in this study is national policy in the field of prevention and eradication of abuse and illicit awareness of narcotics (P4GN) that can be applied in government and private agencies, schools, and universities in Lampung province during the covid-19 pandemic.
\end{abstract}

Keywords- Policy implementation, BNN, P4GN, Covid-19.

\section{INTRODUCTION}

During the Covid-19 pandemic that has hit almost all over the world, Indonesia itself has a profound effect on several aspects of life, such as economic, social, and others. No exception to narcotics circulation in Indonesia. During the economic crisis, many people lost their jobs or livelihoods, and others, the circulation of narcotics increased during the Covid-19 pandemic. The irresponsible circulation of narcotics has become more widespread among the community. Plus the issue of The State of Indonesia is in the pandemic covid-19. This will certainly be more worrying, especially we know that during the pandemic covid-19 that uses narcotics is among the younger generation (the next generation of the nation) which is the hope and focus of the nation in the future. Law enforcement officials have difficulty dealing with this problem of narcotic abuse. So that in this day and age the Indonesian government is actively carrying out development in all fields, both physical development and spiritual development of human beings as fully as born and mental.

One of the serious problems today is the problem of narcotic abuse. Abusers are people who use narcotics without rights or are against the law. According to Rena, narcotics addicts are "self-victimizing victims" i.e. those who are victims because of crimes committed by themselves. Narcotic dependence is a condition characterized by the urge to use narcotics continuously with increased doses to produce the same effect and if their use is reduced or stopped suddenly will cause typical physical and psychic symptoms. In the medical world, drugs are psychotropic compounds commonly used to anesthetize or treat certain diseases with a certain dose as needed. Drug use in Indonesia that does not have permission to use drugs due to the need can cause damage to body tissues and when it enters the body can damage the composition of central nervous function (brain) to cause physical, psychic/mental disorders and social functions. Drug abusers can happen to anyone and anywhere for a variety of reasons why users use drugs.

The government conducts surveillance of all activities related to narcotics. To prevent and eradicate the misuse and illicit circulation of narcotics and precursors of narcotics with Law No. 35 of 2009 established the National Narcotics Agency which is hereinafter abbreviated as BNN which is a NonMinisterial Government Institution (LPNK) domiciled under the President and responsible to the President. Has the task of carrying out the duties of the 
government in the field of prevention and eradication of abuse and illicit circulation of psychotropics, precursors, and other addictive substances except for addictive substances for tobacco and alcohol. BNN is tasked to coordinate relevant government agencies in the composition of policies and their implementation in the field of availability, prevention, and eradication of the misuse and illicit circulation of narcotics, psychotropics, precursors, and other addictive substances. Bawasan in implementing Law No. 35 of 2009, President made a regulation namely Presidential Regulation No. 23 of 2010 concerning the National Narcotics Agency hereinafter referred to as $\mathrm{BNN}$ is a non-ministerial government agency that is located under and responsible to the President [1,2]. The government has made efforts in addressing this problem, namely by the Presidential Instruction No. 12 of 2011 on the Implementation of National Policies and Strategies for the Prevention and Eradication of Abuse and Illegal Drug Distribution (P4GN), covering the field of 1) Prevention; 2) Community Empowerment; 3) Rehabilitation; and 4) Eradication [3]. Through the National Narcotics Agency, the government has been authorized to address drug-related problems. The National Narcotics Agency (BNN) is a Non-Ministerial Government Agency (LPNK) that has the task of compiling and implementing national policies on the prevention and eradication of the misuse and illegal circulation of narcotics and narcotic precursors (P4GN).

The National Narcotics Agency made a strategic plan to address the existing drug problem, contained in the Regulation of the Head of the National Narcotics Agency No. 7 of 2015 on the Strategic Plan of the National Narcotics Agency in 2015-2019. This strategic plan contains a P4GN policy aimed at "Realizing a healthy Indonesian Society, free from drug abuse and trafficking". To help implement this policy in all regions in the form of the Provincial National Narcotics Agency called (BNNP) and the National Narcotics Agency City / District called (BNNK).

Drug abuse and illicit trafficking show an increasing intensity in almost all levels of life, both at the level of education, social status, economy, and age. According to the drug dictionary issued by $\mathrm{BNN}$, drug abuse is a pattern of drug abuse that is clinically deviant, at least one month long, and there has been a disruption of social function or work.

Facing a narcotics problem that tends to continue to increase, law enforcement officials have difficulty in addressing the problem of narcotic abuse. On the other hand, this problem of circulation and abuse is a prohibited act and very dangerous for those who consume it. BNN is expected to help the government to overcome the misuse of narcotics among the community.

The misuse and illegal distribution of narcotics continue to be a serious threat to every country, this is due to the increase in illegal narcotics production and the rapid and widespread distribution of no longer know the boundaries between countries, resulting in the victims of narcotics abuse that every year increases. Strict surveillance efforts by countries around the world have been able to control narcotics trafficking in Europe, the Americas, and Asia. However, the transactions and illegal distribution of narcotics carried out by organized crime perpetrators(organized crime)turned out to be increasing, so it takes a variety of efforts to protect the community from the dangers of narcotics.

Strict surveillance efforts by countries around the world have been able to control narcotics trafficking in Europe, the Americas, and Asia. However, transactions and illicit narcotics carried out by organized crime perpetrators are increasing, so it takes a variety of efforts to protect the community from the dangers of narcotics. BNN carries out its duties through various programs, one of which is the Prevention of Drug Abuse and Trafficking Prevention Program (P4GN) throughout Indonesia.

Based on the problems that have been described earlier, the research was conducted to find out as follows:

- How is the Implementation of the "BNN Provinsi Lampung" Policy in The Prevention of Narcotic Abuse and Trafficking Prevention Program (P4GN) During the Covid-19 Pandemic?

- What are the Inhibitory Factors in the implementation of the policy of prevention program to eradicate the misuse and illegal distribution of narcotics (P4GN) during the covid-19 pandemic implemented by $\mathrm{BNN}$ Lampung Province?

\section{CONTRIBUTION}

\section{A. Theoretically}

It can be a contribution of advice and input for the government, especially for parties who carry out relevant interests, authorities, and policies in the prevention of the eradication of drug abuse and illicit trafficking (P4GN) during the covid-19 pandemic.

\section{B. Practical Uses}

- This research is expected to be a study material on the development of criminal law, especially about narcotics, as well as adding insight, especially about the Prevention of Drug Abuse and Illicit Trafficking (P4GN) during the covid19 pandemic.

- Contributing to academics and practitioners, in looking at criminal law liability, especially narcotics. 
- Giving knowledge to all of us about the dangers of narcotics.

\section{DISCUSSION}

\section{A. Policy implementation}

According to Michael Hill and Peter Hupe (2002) in the Journal of Social Policy on, Implementing Public Policy [4]. Implementation or implementation, as in the webster and roger dictionary is understood as to carry out, accomplish, fulfill, produce, complete. According to the Great Dictionary of The Indonesian Language, it is mentioned that implementation is the implementation, implementation, or fulfillment. Lester and Stewart said that the implementation of the policy is seen in a broad sense, a stage of the policy process immediately after the enactment of the Act. Then Lester and Stewart also mentioned implementation on the other hand is a complex phenomenon that may be understood as a process, an output(output)as well as an impact (outcome). The term implementation refers to several activities that follow a statement of intent about the purpose of the program and the results desired by government officials. Implementation includes actions (without action) by various actors, especially government bureaucrats, who are devoted to making a policy.

Meanwhile, after reviewing various implementation studies, six main factors are considered to contribute to the success or failure of implementation. The six factors are:

- Clear and consistent policy objectives or objectives, i.e. details of the goals to be achieved through policies and standards for measuring their achievements.

- Strong theoretical support in formulating policy, which is the basis in the preparation of policies implemented.

- The implementation process has a clear legal basis to ensure compliance of officers in the field and target groups, namely regulations that govern the stages of policy implementation.

- Support of stakeholders namely supports from various parties related to the implementation of the program in the run.

- Commitment and expertise of policy implementers, namely knowledge and understanding of the content and objectives of the policy; their attitude to the policy; and the intensity of the attitude

- Stability of social, economic, and political conditions, namely aspects of the adequateness of economic resources, how large and how policies can affect the existing socioeconomic conditions, how the public responds to the policy.

\section{B. Implementation Stages}

Subarsono (2008) expressly stated that implementation covers 4 aspects, namely: (1) who is involved in the implementation of the policy, (2) the essence of the administrative process, (3) compliance with the policy, (4) the influence of implementation on the content and impact of the policy [5]. Charles O. Jones in Arif Rohman (2009) stated that implementation is an activity intended to operate a program [6]. There are three pillars of activity in operating the program are (1) organizing, forming, or reorganizing resources, units, and methods to run programs to run; (2) interpretation, i.e. the activity of interpreting the program to be an appropriate and acceptable plan and direction; (3) Application, relating to routine equipment for services, payments, or other customized to the purpose or equipment of the program.

Subarsono (2008) expressly stated that the implementation of the Policy on The Prevention and Eradication of Drug Abuse and Trafficking (P4GN), covers 4 aspects, namely [5]:

- Who is involved in the implementation of the policy, namely the National Narcotics Agency which has direct authority to implement them?

- The essence of the administrative process, all have been established and regulated in Presidential Regulation No. 23 of 2010 concerning the National Narcotics Agency, the Presidential Instruction No. 12 of 2011 on the Implementation of The National Plan and Strategy for the Prevention and Eradication of Drug Abuse and Illicit Circulation (P4GN), and The Regulation of the Head of the National Narcotics Agency No. 7 of 2015 on the Strategic Plan of the National Narcotics Agency in 20152019.

- Compliance with the policy, then what has been set by the policymaker must be implemented by the implementor.

- The effect of implementation on the content and impact of the policy, this P4GN policy must be implemented so that what is the objective of this policy can be achieved and can affect the conditions before this policy is made.

\section{P4GN Policy as Public Policy}

Public policy according to Thomas R. Dye (1981) in Subarsono is whatever the choice of the government to do or not (public policy is whatever governments choose to do or not to do) [7]. The scope of public policy studies is very broad because it covers various fields and sectors such as economics, politics, society, culture, law, and so on. In addition, judging from the hierarchy of public policy can be national, regional, and local such as laws, government regulations, presidential regulations, ministerial regulations, local/provincial government regulations, governor's decisions, 
district/city regulations, and decisions of regents/mayors.

According to David Easton when the government made public policy, that's when the government allocates values to the community because each policy contains a set of values in it (R. Dye, 1981) [7].

The definition of public policy can be said that:

- Public policy is made by the government in the form of government actions;

- Public policy should be oriented towards the public interest;

- Public policy is an alternative electoral measure to be implemented or not implemented by the government in the public interest.

Ideally, a public policy is:

- Public policy is made by the government in the form of government actions;

- Public policy to implement or not implement is based on the public interest itself.

The public policy framework will be determined by the following variables:

- Goals to be achieved;

- What kind of value preferences to consider in policymaking;

- Resources that support policies;

- The ability of actors involved in the making of policy;

- Environments that include socio-political environments, and so on;

- Strategies used to achieve goals.

1) Types of Public Policy

Public policy has a considerable barrage, but it can simply be grouped into three types.

- Public policies that are macro or general, or basic (Law Regulations, Government Regulations, Presidential Regulations, and Local Regulations)

- Public Policy that is messo or medium, or the explanation of the implementer (Ministerial Regulation, Ministerial Circular Letter, Governor Regulation, Regent Regulation, and Mayor)

- The micro-public policy is a policy that regulates the implementation of policies on it, the form of policy is a regulation issued by the public apparatus under ministers, governors, regents, and mayors.
By referring to the grouping of the above types of policies, the policy of Prevention and Eradication of Drug Abuse and Trafficking (P4GN) namely Presidential Instruction No. 12 of 2011 is a type of macro policy. Furthermore, it is continued with the Regulation of the Head of the National Narcotics Agency No. 7 of 2015 concerning the Strategic Plan of the National Narcotics Agency in 2015-2019 which is a type of messo policy.

In the policy process, there are steps to find out if the policy is in line with the objectives and can resolve the issue. In this study, researchers want to discuss one of the policy stages, namely the policy implementation stage.

In policy implementation, there are at least three important elements to consider:

- The existence of programs or policies implemented.

- Target group or community groups that are targeted and are expected to provide benefits and changes and improvements.

- Elements of implementation, both organizations, and individuals who are responsible for the management, implementation, and supervision of the implementation process.

Meanwhile, according to Grindle in Winarno (2012) implementation in general forms, a linkage that facilitates policy objectives can be realized as a result of a government activity [8]. Therefore, the task of implementation includes the establishment of a policy delivery system, in which certain means are designed and executed with the hope of arriving at the desired goals.

It can be concluded that the implementation is a series of actions that have been carried out by the government as a form of realization of a policy and implemented following the prevailing legal basis implemented by the implementer of the policy to achieve the stipulated tuuuan.

\section{Supporting Factors and Inhibitions of implementation}

According to George Edward III, the factors that influence the implementation of P4GN policy in the P4GN prevention programs with 4 variables that affect: Communication, Resources, Disposition, and Bureaucratic Structure.

\section{1) communication}

Communication is important in all activities that involve more than one party. This communication will always be needed to coordinate from one party to another to achieve the goals that have been set together. This communication is needed to convey all relevant information about what is being done that involves both 
parties to make it easier to achieve the goal. Similarly, with the implementation of public policy, in the process of implementation of public policy, there needs to be communication between public policy implementers and public policy users for the implementation of public policy to run.

According to Goerge C. Edward III, communication is to point out that every policy will be implemented properly in case of effective communication between program implementers (policies) and target groups. The objectives and objectives of the program/policy can be well socialized to avoid distortions in policies and programs. Communication is one of the important variables that affect the implementation of public policy. The existence of communication makes clarity of standards, objectives, and policy objectives will be able to be informed not only from superiors to subordinates but also to target groups. Therefore, communication is very determining the success of achieving the objectives of public policy implementation. Communication does play an important role in coordination and implementation in general.

\section{2) Resources}

The existing resources are undeniably an influential factor in the implementation of existing public policies. If not owned resources then existing public policies can not be implemented. The process of implementing the public policy will always depend on the resources owned, the more able to utilize the resources owned, the easier it will be in carrying out the public policy. Resources in the process of implementing public policy can be seen from many forms of resources owned.

According to Edward resources, namely appointing every policy must be supported by adequate resources, both human resources and financial resources. Human resources are adequacy of both quality and quantity of implementors that can cover the entire target group. Financial resources are the adequacy of investment capital for a program/policy.

\section{3) disposition}

In the implementation of existing public policies, there are also characteristics of implementing agents that can help the implementation process of public habits. The characteristics of this implementing agent will adjust to the public policy that will be applied to the target group. The disposition or attitude of the policy implementer is an important factor in the implementation of a public policy. According to George Edward III, the disposition of this implementor is about the character and characteristics (attitudes) possessed by implementors such as commitment, honesty, and democratic nature, and so on. If the implementor has a good disposition, then he will be able to run the policy well as expected by the policymakers.

\section{4) Bureaucratic structure}

The bureaucratic structure is also one of the factors that can affect the implementation can run well or not. Even if the resources for implementing a policy are available, or the policy implementers are available or the policy implementers know what to do, and have the desire to implement a policy, likely, the policy cannot be implemented or realized because of weaknesses in the bureaucratic structure. In the process of implementing challenges is how bureaucracy does not arise or occur fragmentation, the dimension of fragmentation confirms that fragmented bureaucratic structures can increase communication failure, where policy implementers will be distorted. In other words, bureaucratic fragmentation can be an implementation process far from an effective word.

To support the successful implementation of the policy, standard operational procedures (SOP) are required. SOP is required as operational guidelines

for each policy implementor. In addition, the bureaucratic organizational structure should be designed in such a way as to avoid procedures that are too long and convoluted and of course to facilitate supervision On the implementation of the P4GN BNN policy certainly has operational standards procedures or SOP for its implementation.

\section{CONCLUSION}

During a covid pandemic like this, of course, the implementation of the P4GN policy in Lampung Province has not been optimal. This is known from the many obstacles that occur in the field where all activities outside are hampered because of the pandemic covid 19 and other inhibitory factors that affect the implementation of P4GN policy in Lampung Province conducted by BNN some factors support and that can be seen from 4 variables, namely communication, resources, disposition, bureaucratic structure. Researchers are very concerned that this pandemic is coming to an end so that the implementation of this policy is immediately implemented and there are no more cases of drug abuse that are troubling many parties.

\section{REFERENCES}

[1] Law No. 35 of 2009 on Narcotics

[2] Presidential Regulation No. 23 of 2010 concerning the National Narcotics Agency

[3] Presidential Instruction No. 12 of 2011 on Implementation of National Policies and Strategies for The Prevention and Eradication of Drug Abuse and Trafficking (P4GN)

[4] M. Hill and P. Hupe. Implementing public policy: Governance in theory and in practice. Sage, 2002.

[5] Subarsono, Public Policy Analysis: Concepts, Theories And Applications. Yogyakarta: STUDENT LIBRARY. 2013.

[6] C. O. Jones. The presidency in a separated system. Brookings Institution Press, 2005.

[7] Thomas R. Dye, Understanding Public Policy, New Yersey, 1981. 
[8] B. Winarno. Public Policy (Theory, Process, and Case Studies). CAPS (Center Of Academic Publishing Service). Yogyakarta. 2014.

[9] Anshoruddin, The Law of Proof of Islamic Procedural Law and Positive Law, Student Library. Yogyakarta. 2004.

[10] Arief, Nawawi, Barda. Potpourri Of Criminal Law Policy. Aditya Bakti's image, Bandung, 1996.

[11] Arief, Nawawi, Barda. Law Enforcement Issues and Crime Prevention Policy, Aditya Bhakti, Bandung, 2001.

[12] Fuady, Munir, Unlawful Acts. Contemporary Approach. Pt. Aditya Bakti's image, Bandung, 2005.
[13] Hamzah, Andi. Introduction to Criminal Procedural Law, Ghalia Indonesia, Jakarta, 1985.

[14] Hamzah, Andi. Indonesian Criminal Procedural Law, Revised Edition, Sinar Grafika, Jakarta, 2001.

[15] Handoyo Eko. Public Policy, Semarang: CV. Widya Karya, 2012.

[16] Kartono, Kartini. About the Eradication of Criminal Acts National Narcotics Agency Data Journal. 2012, Jakarta, 2001.

[17] G. Supramono. Indonesian Narcotics Law. Djambatan, Jakarta, 2001. 